\title{
Ekstrakcja zęba siecznego dolnego u pacjentów z I klasą - przegląd piśmiennictwa kazuistycznego
}

\section{Extraction of a lower incisor in patients with Class I malocclusion - a review of case reports}

1 Studenckie Koło Naukowe Ortopedii Szczękowej i Ortodoncji, Uniwersytet Medyczny im. Karola Marcinkowskiego w Poznaniu Students Scientific Society of Department of Maxillofacial Orthopaedics and Orthodontics,

Poznan University of Medical Sciences, Poland

${ }^{2}$ Katedra i Klinika Ortopedii Szczękowej i Ortodoncji, Uniwersytet Medyczny im. Karola Marcinkowskiego w Poznaniu Chair and Department of Maxillofacial Orthopaedics and Orthodontics, Poznan University of Medical Sciences, Poland

DOI: http://dx.doi.org/10.20883/df.2021.6

\begin{abstract}
STRESZCZENIE
Jedną z metod leczenia ortodontycznego jest ekstrakcja jednego z siekaczy w żuchwie. Jest ona stosowana najczęściej w celu wyeliminowania stłoczeń w dolnym łuku. Materiał i metody: Przeszukano internetowe bazy medyczne Google Scholar i PubMed. Po analizie wybrano 8 prac kazuistycznych opisujących leczenie ortodontyczne pacjentów z I klasą. Wyniki: Wszystkie przypadki przedstawiały leczenie osób młodych (przedział wieku: 12-19 lat) charakteryzujących się stłoczeniem zębów w dolnym lub dolnym i górnym łuku. Wnioski: Wybór leczenia ortodontycznego z wykorzystaniem ekstrakcji jednego z siekaczy w żuchwie powinien uwzględniać wiele czynników i być poprzedzony indywidualnie opracowanym planem leczenia.
\end{abstract}

Słowa kluczowe: leczenie ortodontyczne, siekacz dolny, ekstrakcja, I klasa.

\section{ABSTRACT}

One of the methods of orthodontic treatment is the extraction of one incisor in the mandible. It is most often used to eliminate crowding in the lower arch. Material and methods: Google Scholar and Pubmed online medical databases were searched. After the analysis, 8 case reports describing orthodontic treatment in class I patients were selected. Results: All cases involved the treatment of young people (age range: 12-19 years old) with crowding in the lower or upper and lower arches. Conclusions: The choice of orthodontic treatment with the use of extraction of one of the mandibular incisors must take into account many factors and be preceded by an individualized treatment plan.

Keywords: orthodontic treatment, lower incisor, extraction, class I malocclusion.

\section{Wstęp}

Pośród opcji leczenia ortodontycznego znajdują się rozwiązania ekstrakcyjne i bezekstrakcyjne. Wybór ten jest wyzwaniem dla klinicystów i zależy od wielu czynników; posiada wady i zalety w obu przypadkach. Kokich i Shapiro [1984] w oparciu o przypadki kliniczne dowiedli, że ekstrakcje dolnych siekaczy pozwalają osiągnąć czynnościową okluzję i kosmetyczne rezultaty, używając minimalnej ortodontycznej interwencji. Oczywiście, jak w większości przypadków, istnieją przeciwwskazania do wyboru tej metody. Należy do nich duży nagryz pionowy [Tuverson, 1980], gdyż w trakcie postępu zamykania się przestrzeni poekstrakcyjnej może ulec dodatkowemu zwiększeniu. Zaletą wyboru usunięcia dolnych siekaczy nad usunięciem przedtrzonowców i nieekstrakcyjnymi metodami jest brak zwięk- szenia odległości między kłami w żuchwie [Klein, 1997]. lleri i wsp. [2011] porównali opcję bezekstrakcyjną z ekstrakcyjną, w tym z ekstrakcją czterech pierwszych zębów przedtrzonowych oraz ekstrakcją dolnego siekacza u pacjentów z I klasą Angle'a i stłoczeniem zębów. Na podstawie wskaźnika PAR stwierdzili, że leczenie bezekstrakcyjne cechuje się lepszymi wynikami niż ekstrakcyjne. Jednakże ekstrakcje wykonuje się w różnych przypadkach klinicznych. Biswas i wsp. [2018] zestawili przypadki ekstrakcji siekaczy dolnych w różnych klasach Angle'a, podając wiele wskazań do tego zabiegu, takich jak: nadmierny mezjalno-dystalny wymiar siekaczy w żuchwie, zmniejszony mezjalno-dystalny wymiar siekaczy w szczęce, ektopiczna erupcja siekaczy, zaawansowany stopień redukcji przyzębia czy choroba próchnicowa obejmująca dany ząb. Podkreślają oni również, że za- 
bieg ten powinien być poprzedzony diagnostycznym setupem, aby osiągnąć optymalną okluzję.

\section{Cel}

Praca ma na celu ukazanie przykładów leczenia ortodontycznego z ekstrakcją siekaczy w żuchwie u pacjentów z I klasą.

\section{Materiał i metody}

Przeszukano internetowe bazy medyczne PubMed i Google Scholar z lat 2016-2021, stosując hasła indeksowe: mandibular incisor, extraction, orthodontic treatment case report. Odnaleziono około 15800 pozycji. Po przeanalizowaniu wybrano 17 prac, następnie wyodrębniono 8 prac opisujących leczenie ortodontyczne pacjentów z I klasą.

\section{Wyniki}

Wybrane publikacje piśmiennictwa zestawiono w tabeli 1. Wszystkie przypadki cytowanych doniesień przedstawiają leczenie ortodontyczne z ekstrakcją siekacza dolnego u ośmiu młodych osób w przedziale wieku od 12 do 19 lat. Rozkład płci pacjentów jest równy - 4 płci męskiej i 4 żeńskiej. Wszyscy opisani pacjenci mieli I klasę Angle'a. I klasę szkieletową stwierdzono u 6 z nich; w dwóch przypadkach nie została ona uwzględniona [Agarwal i Gupta, 2016, Monisha i Arvind, 2017]. W czterech przypadkach [Negi i Negi, 2017, Felicita, 2017, Hwang i wsp., 2018, Singh i wsp., 2018] wykonano cefalometrię przed i po leczeniu oraz opublikowano jej wyniki. Każdy z ośmiu przypadków przed leczeniem cechował się stłoczeniem zębów w dolnym łuku, $w$ tym sześć również $w$ górnym [Agarwal i Gupta, 2016, Negi i Negi, 2017, Felicita, 2017, Servin Muñoz i wsp., 2017, Monisha i Arvind,2017, Singh i wsp., 2018]; opisywane jako łagodne, umiarkowane lub ciężkie w 2 przypadkach bez podania zaawansowania [Negi i Negi, 2017, Felicita, 2017]. We wszystkich przypadkach po terapii zostało stłoczenie wyeliminowane, jednakże w 7 na 8 przypadków zastosowano retencję stałą w łuku dolnym.

Wszyscy pacjenci byli leczeni ortodontycznie z ekstrakcją zębów (prawego centralnego siekacza żuchwy w trzech przypadkach, lewego centralnego siekacza żuchwy w trzech przypadkach oraz prawego bocznego siekacza żuchwy w dwóch przypadkach) z wykorzystaniem aparatu stałego. W sześciu przypadkach [Beycan i Acar, 2016, Agarwal i Gupta, 2016, Negi i Negi, 2017, Servin Muñoz i wsp., 2017, Hwang i wsp., 2018, Singh i wsp., 2018] uwzględniono czas leczenia; odpowiednio: 16, 16, $18,16,24,23$ miesiące.

\section{Dyskusja}

Opisane w piśmiennictwie przypadki to osoby płci żeńskiej w wieku od 13 do 15 lat oraz płci męskiej w wieku od 12 do 19 lat. Usuwanie zębów siecznych w żuchwie dotyczy wielu sytuacji klinicznych, jednakże powinno uwzględniać wiek pacjenta. Terapia ortodontyczna u osób z niezakończonym okresem wzrostu może wymuszać stałą retencję do jego zakończenia, jak sugerował Schudy [1974], a nawet dłużej szczególnie u mężczyzn. Nanda i Gosh [1995] stwierdzili, że najintensywniejszy wzrost przypada na okres od 6 do 12 lat dla kobiet, a dla chłopców od 12 do 18 lat. Zbadano, iż żuchwa wydłuża się dwukrotnie bardziej niż szczęka w wieku od 6 do 20 lat; przy czym u mężczyzn o 2 lata dłużej niż u kobiet [Ochoa i Nanda, 2004]. Wzrost żuchwy może mieć wpływ na ułożenia zębów w odcinku przednim żuchwy. Biorąc te fakty pod uwagę, metody ekstrakcyjne dla osób w wieku dynamicznego wzrostu mogą być uważane za kontrowersyjne. Żaden z autorów cytowanych prac nie podał czasu, po którym miałaby zostać usunięta retencja stała.

Z piśmiennictwa wynika, że opisywane wyniki przypadków ekstrakcji siekacza w żuchwie dotyczą zarówno młodzieży jak i dorosłych osób. Sah i wsp. [2018] opisali przypadek 29-letniego mężczyzny, u którego przeprowadzono ekstrakcję prawego bocznego siekacza żuchwy, osiągając wyeliminowanie umiarkowanego stłoczenia $w$ dolnym łuku oraz przesunięcie linii pośrodkowej. Podczas podejmowania decyzji, który z siekaczy powinien zostać usunięty, należy rozważyć kilka czynników. Jednym z nich jest wybór zęba, w którym stwierdza się redukcję tkanek przyzębia. W opisie Agarwal i Gupta [2016] podali, że przy usuwanym zębie widoczna była znaczna recesja dziąsła, dodatkowo znajdował się on poza łukiem zębowym od strony przedsionka, co również stanowiło powód, dla którego został usunięty. Podobnie jak w pracach Monisha i wsp. [2017] oraz Felicita [2017] usunięty siekacz znajdował się po językowej stronie łuku.

Suleman i wsp. [2018] dowiedli, iż stłoczenie było najczęstszym powodem ekstrakcji dolnego siekacza (67\%) wśród 92 pacjentów. Jednakże istnieją alternatywne metody eliminacji stłoczeń. Jedną z nich jest stripping zębów. Germeç i Taner [2008] już 10 lat wcześniej stwierdzili, że stripping jest równie efektywną metodą w leczeniu umiarkowanych stłoczeń u pacjentów z klasą I i dobrym profilem twarzy jak ekstrakcyjne metody. Należy mieć również na uwadze, iż w opcji ekstrakcyjnej trudnością może się okazać zamykanie przestrzeni poekstrakcyjnej, a w strippingu zmniejszenie gru- 


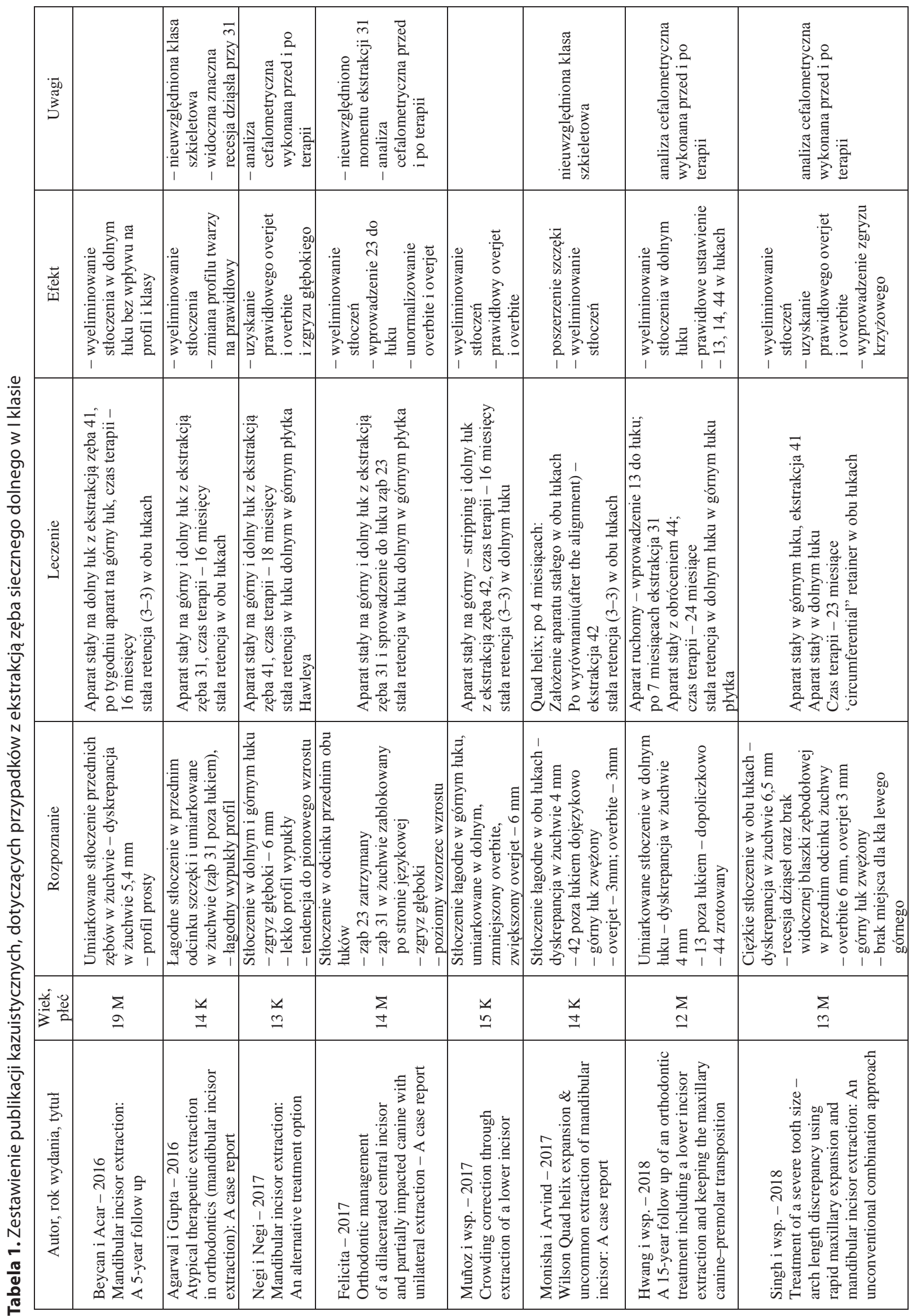


bości szkliwa, co może powodować nadwrażliwość i wzrost ryzyka wystąpienia próchnicy.

\section{Wnioski}

Wybór metody leczenia z ekstrakcją siekacza w żuchwie musi być indywidualnie opracowanym planem leczenia dla każdego z pacjentów na podstawie pełnej dokumentacji. Klinicysta powinien wziąć pod uwagę wiele czynników, takich jak wiek pacjenta, stan przyzębia w okolicach usuwanego zęba oraz przewidzieć rezultaty jeszcze przed rozpoczęciem terapii.

\section{Oświadczenia}

Oświadczenie dotyczące konfliktu interesów Autorzy deklarują brak konfliktu interesów w autorstwie oraz publikacji pracy.

\section{Źródła finansowania}

Autorzy deklarują brak źródeł finansowania.

\section{References}

[1] Kokich VG, Shapiro PA. Lower incisor extraction in orthodontic treatment: four clinical reports. Angle Orthod. 1984;54(2):139-153. English.

[2] Tuverson DL. Anterior interocclusal relations Part II. Am J Orthod. 1980;78(4):371-393. English.

[3] Klein DJ. The mandibular central incisor, an extraction option. Am J Orthod Dentofacial Orthop. 1997;111(3):253-259. English.

[4] Ileri Z, Basciftci FA, Malkoc S, Ramoglu SI. Comparison of the outcomes of the lower incisor extraction, premolar extraction and non-extraction treatments. Eur J Orthod. 2012;34(6):681-685. English.

[5] Biswas PP, Bavitha TK, Rijash UV, Jaibai D, Hridya KG. Indications for lower incisor extraction-A case series review. Int J Oral Health Dent. 2018;4(1):1-5. English.

[6] Beycan K, Acar A. Mandibularincisorextraction:a 5-year follow-up. J Istanbul Univ Fac Dent. 2016;50(3):62-66. English.

[7] Agarwal L, Gupta A. Atypical therapeutic extraction in orthodontics (mandibular incisor extraction): A case report. Int J Oral Health Dent. 2017;2(4):260264. English.

[8] Negi N, Negi KS. Mandibular Incisor Extraction: an alternative treatment option. Int J Health Sci Res. 2017;7(3):366-369. English.

[9] Felicita AS. Orthodontic management of a dilacerated central incisor and partially impacted canine with unilateral extraction-A case report. Saudi Dent J. 2017;29(4):185-193. English.

[10] Muñoz MS, Martínez BG, Araujo AC. Crowding correction through extraction of a lower incisor. Rev Mex de Ortodon. 2017;5(2):67-71. English.
[11] Monisha L, Arvind W. Wilson Quad Helix Expansion and Uncommon Extraction of Mandibular Incisor: A Case Report. Biomed Pharmacol J. 2017;10(3):13791383. English.

[12] Hwang S, Kim I, Jang W, Choi YJ, Chung CJ, Kim KH. A 15-year follow up of an orthodontic treatment including a lower incisor extraction and keeping the maxillary canine-premolar transposition. Angle Orthod. 2019;89(5):812-826. English.

[13] Singh H, Kapoor P, Sharma P, Maurya RK, Mittal T, Bhagat DK. Treatment of a severe tooth size-arch length discrepancy using rapid maxillary expansion and mandibular incisor extraction: An unconventional combination approach. J Indian Orthod Soc. 2019;53(1):69-76. English.

[14] Schudy GF. Posttreatment craniofacial growth: its implications in orthodontic treatment. Am J Orthod. 1974;65(1):39-57. English.

[15] Nanda RS, Ghosh J. Longitudinal growth changes in the sagittal relationship of maxilla and mandible. Am J Orthod Dentofacial Orthop. 1995;107(1):79-90. English.

[16] Ochoa BK, Nanda RS. Comparison of maxillary and mandibular growth. Am J Orthod Dentofacial Orthop. 2004;125(2):148-159. English.

[17] Sah JK, Mishra P, Shrestha RM, Gupta A. Treatment of Class I Malocclusion with a Lower Incisor Extraction: A Case Report." Orthod J Nepal. 2018;8(1):58-62. English.

[18] Suleman S, Khan WU, Yousafzai IK, Shafique S, Gul T. Various reasons of mandibular incisor extraction in orthodontic patients. POJ. 2018;10(2);111-115. English.

[19] Germeç D, Taner TU. Effects of extraction and nonextraction therapy with air-rotor stripping on facial esthetics in postadolescent borderline patients. Am J of Orthod Dentofacial Orthop. 2008;133(4):539549. English.

Zaakceptowano do edycji: 28.06.21 Zaakceptowano do publikacji: 29.09.21

Adres do korespondencji:

Katedra i Klinika Ortopedii Szczękowej

i Ortodoncji Uniwersytetu Medycznego im. Karola

Marcinkowskiego w Poznaniu

ul. Bukowska 70

60-812 Poznań

tel.: 790519287

e-mail: karolinalukaszewicz123@gmail.com 